\title{
Relations between Innovation and Firm Performance of Manufacturing Firms in Southeast Asian Emerging Markets: Empirical Evidence from Indonesia, Malaysia, and Vietnam
}

\author{
Kyunga $\mathrm{Na}^{1}$ and Young-Hee Kang ${ }^{2, *}$ \\ 1 Department of Accounting \& Taxation, College of Business Administration, Keimyung University, \\ Daegu 42601, Korea; kyunga@kmu.ac.kr \\ 2 Department of Business Administration, College of Business Administration, Keimyung University, \\ Daegu 42601, Korea \\ * Correspondence: kang02@kmu.ac.kr
}

Received: 1 November 2019; Accepted: 3 December 2019; Published: 7 December 2019

\begin{abstract}
This study aims to investigate the effects of product and process innovations on manufacturing firm performance in Southeast Asian emerging markets. To this end, using a cross-national sample of 2324 manufacturing firms from the World Bank Enterprise Survey (WBES) dataset of 2015, we test the effects of product and process innovations on the sales growth of manufacturing firms in Vietnam, Malaysia, and Indonesia. This study finds that product innovation is positively related to sales growth while new operating technologies are negatively associated with sales growth. For high-tech firms, product innovation is positively related to sales growth. The findings imply that in Southeast Asian emerging markets, governments and manufacturing firms can enhance performance by investing in product innovation.
\end{abstract}

Keywords: innovation; Southeast Asian emerging markets; sales growth; manufacturing; Indonesia; Malaysia; Vietnam

\section{Introduction}

Innovation has been regarded as an essential element for a nation's economic growth, as well as a firm's competitiveness [1]. Innovation has become extremely relevant for firm sustainability in the current global markets, where knowledge based competition is becoming more apparent. Traditional research on innovation has focused on firms in developed economies because innovation has been usually associated with the latest knowledge, skill, or technology. Meanwhile, research on firm innovation in emerging markets has placed weight on determinants of firm innovation such as R\&D activities [2-5] and top managers' characteristics [6,7]. These research streams have left the innovation activities in emerging markets relatively unknown. There is a lack of literature on firms' innovation activities in the Asian emerging markets. As innovation activities require high capital, skills, and risk [8], businesses in transition economies are often limited in making significant innovations. As such, existing studies have paid attention to innovation barriers of emerging markets $[9,10]$ rather than the firm innovation-performance link. In particular, except for China and India [11-13], there is a lack of literature on the effectiveness of firms' innovation activities in the Asian emerging markets.

Recently, Southeast Asian transition economies have drawn much attraction as a production base, as well as a consumer market because they have a young and large scale population and increasing purchasing power. Moreover, with the establishment of the ASEAN (Association of Southeast Asian Nations) Economic Community (ACE) in 2015, the ASEAN region is expected to be the second largest 
economy in the world by 2050 ([14] and [15] (p. 2)). Despite the increasing growth of Southeast Asian emerging markets, there are few studies on the role of innovation in firm growth or productivity in Southeast Asian emerging markets [16,17].

Among the ASEAN nations, Indonesia, Malaysia, and Vietnam have taken the spotlight because they have great potential for economic growth. Foreign direct investment (FDI) and the number of global companies entering these countries have shown a steep increase; in terms of the gross domestic products (GDP), Malaysia and Indonesia are included in the top three nations from ASEAN [18]; Vietnam has a big domestic market with around 100 million of the population, a great amount of natural resources, and an inexpensive labor force; and these countries have placed great emphasis on innovation, but their innovation levels are still low [16]. Yet, little research on innovation at the firm level in these countries has been performed [19]. Specifically, there is a need for empirical evidence on the link between innovation and firm performance at the firm level.

The manufacturing industry has contributed to the economic growth and employment of these countries, although the share of the sector in GDP is declining. For Malaysia, small and medium enterprises (SMEs) account for the majority of manufacturing [20]. Intense competition requires SMEs to be more innovative in order to obtain competitive advantages over local and foreign rivals. According to Rosli and Sidek [20], both product and process innovations are positively related to overall firm performance in Indonesia. For Indonesia, between 1990 and 2016, the share of manufacturing sector accounted for 26.7-40 percent of GDP [21]. During the same period, the employment growth in manufacturing was positively associated with GDP growth [21]. However, Indonesian firms have suffered from a lack of technological development, which results from insufficient R\&D budgets and inadequate education [10] (p. 1197). As such, Indonesian firms rely on foreign companies to enhance their technological capabilities [22]. For future development, technological innovation such as product innovation and process innovation has been emphasized in Indonesia [10,21]. In terms of Vietnam, manufacturing firms have played a critical role in Vietnam's economic growth and the improvement of employment. Although Vietnam has been considered recently as a manufacturing hotspot in Southeast Asia, it should be more innovative in order to obtain a competitive edge in the global and regional markets because it is a latecomer among ASEAN. In this line, scholars and practitioners have placed importance on product and process innovation in Vietnam [8].

In sum, these countries have placed great emphasis on innovation, but their innovation levels are still low [16,23], and little research on innovation at the firm level has been performed [19]. Specifically, there is a need for empirical evidence on the link between innovation and firm performance at the firm level.

As there are various innovation activities, it is necessary to examine the type of innovation that affects a firm's performance. According to Dosi [24] (p. 222), innovation refers to "the search for, and the discovery, experimentation, development, imitation and adoption of new products, new production processes and new organizational set ups". Ultimately, innovation is expected to bring a new product, process, or service to the market [25]. In particular, $R \& D$ investments are expected to result in the development or creation of a new product [26,27], i.e., product innovation. In the manufacturing sector, this type of innovation has been regarded as an especially critical factor affecting firm change or renewal $[28,29]$. Innovation in the production process, i.e., process innovation, plays an equally important role in a manufacturing firm's performance because it can save cost or contribute to the improvement of product quality.

In addition, for manufacturing firms, the effectiveness of innovation can differ according to the level of technology used by the industry. Existing research on innovation has mainly focused on the high-tech industries [30] because innovation is often used synonymously for R\&D activities such as technological development. However, for Southeast Asian emerging markets, the manufacturing industry has a high proportion of low- and medium-tech industries. Consequently, rather than the latest technology and technological innovation, incremental process innovations may be effective in these countries. 
This study aims to fill the gap in the literature by examining the effectiveness of the innovation of manufacturing companies in Southeast Asian emerging markets. To this end, using a cross-national sample of manufacturing firms in Vietnam, Malaysia, and Indonesia, the current research will investigate the effects of product innovation and process innovation on firm performance proxied by sales growth.

This research is expected to provide several theoretical and managerial implications. First, this study will contribute to enriching the literature on innovation in Southeast Asian emerging markets by testing the effectiveness of the product and process innovation of manufacturing firms in Vietnam, Malaysia, and Indonesia. There are few empirical studies that deal with process innovation at the firm level [31]. Drawing on a cross-national sample of 2324 manufacturing firms from the World Bank Enterprise Survey (WBES) dataset, this study explores the effects of process and product innovations on firm performance. Moreover, the findings from this study will help understand which type of innovation has more positive effects on firm performance according to technology levels. In addition, the findings from the current study may provide useful suggestions for companies that are running business in or considering entering Southeast Asian emerging markets.

\section{Literature Review}

\subsection{Innovation in Emerging Markets}

Innovation is required for the survival and the achievement of sustainable growth in both transitional and developed economies $[2,7,32,33]$. This is particularly true in emerging markets: while these markets are characterized by fast growing, less developed economies, firms are limited from obtaining other resources for firm growth. Consequently, many studies have placed great emphasis on the effect of innovation on a firm's competitiveness and performance in emerging markets [2,7,12,19,32,34,35]. For example, Kurt and Kurt [32] found that innovation was positively associated with labor productivity in the BRIC (Brazil, Russia, India, and China) region. Atalay et al. [2], who attempted to identify the types of technological innovation that contribute to the improvement of firm performance, used a sample from the Turkish automobile industry and found that technology innovation is positively associated with firm performance. Lynch and Jin [12] found that for Chinese automobiles, both non-technical and technical innovations are effective at meeting the global standards.

Another branch of literature on innovation in emerging markets has paid great attention to the determinants of firm innovation [3,5,36,37] and institutional characteristics facilitating innovation [4]. For example, Ayyagari et al. [3] found that access to external financing, highly educated managers, and multinational competitors are positively associated with innovation in emerging markets. Zhou et al. [38] found that state ownership is negatively related to firm innovation in the Chinese manufacturing industry. By performing a case study across 16 Korean and Indonesian firms, Yun et al. [39] found that the openness of innovation, i.e., whether innovation was developed internally or by adapting external sources, was influenced by regional and national innovation systems. Yun et al. [40] performed a simulation study and found that the strength of policies that promote open innovation led to different levels of improvements in national competitiveness. Yun et al [41] investigated the existing literature to develop a new conceptual framework for innovation, suggesting that innovation was influenced by industrial practices, governmental policies, engagement with academia, and social responsibility.

As demonstrated, the mainstream of research on innovation in emerging markets has focused on identifying ways to promote firm innovation while overcoming poor innovation infrastructure [42]. However, innovation comes in many different forms, such as operation innovations (such as innovation in technology, products, or processes), organizational innovations, marketing innovations, and logistics innovations [7]). For manufacturing firms, two types of innovation are particularly relevant: product innovation and process innovation. The former is quite obvious: new products often give the firm an edge in the market. Meanwhile, the latter can be one of the critical factors that influences firm 
productivity because it can result in the decrease in the production cost. Therefore, product and process innovations need to be discussed as a potential factor in firm performance in emerging markets.

\subsection{Product Innovation and Firm Performance}

Among the different types of innovation, product innovation has been often regarded as a direct measure of a firm's innovation efforts. Product innovation is generally associated with the introduction of a physically new product $[43,44]$ or improvements on existing products [45]. Companies can be more competitive because innovated products lead to improving customer satisfaction. Many studies provide support for the effectiveness of product innovation on firm performance [46-50]. For instance, Varis and Littunen [50] found that the introduction of a new product has positive impacts on firm performance. Camison and Lopez [49] showed that product innovation is central to gaining competitive advantages in the manufacturing sector [49], which contributes to protecting a firm from competitors and market threats [51].

Product innovation can be further separated into radical and incremental innovation based on the novelty of product innovation. Radical product innovation refers to the creation of a completely new product, while incremental innovation refers to the improvement of an existing product. For a comprehensive understanding of the effectiveness of product innovation, innovation refers to both radical and incremental innovation in the current study.

\subsection{Process Innovation and Firm Performance}

The mainstream of research on innovation in emerging markets tends to focus on product or technological innovation. However, as demonstrated by Lynch and Jin [12], non-technological innovation can also improve firm performance. Thus, it is important to investigate the effect of non-technological innovation on firm performance in emerging markets as well.

One of the important non-technological innovations for manufacturing firms is process innovation, i.e., innovation in the manufacturing processes. According to Papinniemi [52], the main purpose of process innovation in manufacturing processes is to create an additional value or to save costs. Specifically, process innovation involves "change potential in manufacturing process characteristics" such as change in man-machine-computer connections, change in the emphasis of key operations, and change in the process in the integration extent [52] (p. 99). Rosenberg [53] claimed that process innovation likely involves automation in production methods rather than strategic decision-making, while Yun and Liu [54] discussed the role of both changes in processes and business models in existing industries that have adopted new technology, dubbed "converted industries". Process innovation can also include capital equipment of different vintages or changes in distribution and organizational practices. Process innovation can also mean the introduction of a new or enhanced technique, tool, device, or knowledge into making a product $[45,55,56]$. Oke et al. [55] asserted that process innovation involves an improvement in technique or process: in other words, changes in the skills, techniques, or procedure of transforming inputs into outputs [57]. This implies that process innovation can play a critical role in gaining competitive advantages. In fact, it has been shown that process innovation has positive effects on firm performance [58] such as firm growth [59], firm productivity [31,60], as well as industrial development [53].

Analogous to product innovation, process innovation can be categorized into radical and incremental innovation based on the novelty of the innovation to the industry. According to Reichstein and Salter [31], incremental process innovations refer to "process innovations that are new to the firm but not new to the industry", while radical process innovations refer to process innovations that are new to the entire industry. For a better understanding of the effectiveness of process innovation, this study deals with both radical and incremental process innovation. 


\subsection{Technology Levels and Innovations}

The type of product and process innovations can vary across different segments of the manufacturing sector due to their unique characteristics. The manufacturing industry can be segmented into high-tech (HT), medium-tech (MT), and low-tech (LT) sectors by the OECD, a categorization that has become widely used [61]. This distinction is based on the extent of investment in R\&D [61]. For example, HT industries are more likely to invest in R\&D than LT and MT industries: HT industries have been regarded as knowledge intensive sectors that require the latest technical knowledge, while LT and MT industries have been perceived as requiring low levels of knowledge [30] (p. 15).

Based on the criteria for the categorization, it follows that technological innovation that is associated with developing the latest technical knowledge, i.e., radical innovation, would be extremely important for HT industries. In contrast, innovation in LT and MT firms is likely to involve adapting existing technology rather than developing the latest technological knowledge [62]. In particular, LT and MT industries are more likely to utilize innovation created in HT industries [63]. LT and MT firms can also benefit from non-R\&D innovation activities [64], such as the integration of knowledge generated from external sectors or other industries $[30,65]$.

\section{Research Method}

\subsection{Data and Sample}

Since the early 2000s, the World Bank has surveyed emerging market firms on their experiences and the business environments in which they operate and constructed the World Bank Enterprise Survey (WBES). In particular, the WBES includes important, objective firm level information such as firm performance, financing, corruption, and infrastructure. The sample firms were collected from this dataset.

We selected manufacturing firms in three Southeast Asian countries, Malaysia, Vietnam, and Indonesia, from the WBES. After deleting all missing values, the final sample size was 2324 firms. Among them, 30.21\% (702) came from Vietnam; 45.91\% (1067) from Indonesia; and 555 (23.88\%) from Malaysia (see Table 1).

Table 1. Sample distribution by country.

\begin{tabular}{ccc}
\hline Country & Firms & \% \\
\hline Vietnam (fiscal year 2014) & 702 & 30.21 \\
Indonesia (fiscal year 2014) & 1067 & 45.91 \\
Malaysia (fiscal year 2014) & 555 & 23.88 \\
\hline Total & 2324 & 100.00 \\
\hline
\end{tabular}

Table 2 shows the characteristics of the overall sample. While $12.91 \%$ and $15.49 \%$ of firms came from the high-tech industry (publishing, printing, and recorded media (industry code: 22), refined petroleum product (industry code: 23 ), chemicals (industry code: 24 ), and precision instruments (industry code: 33 )) and the medium-tech industry (plastics and rubber (industry code: 25), machinery and equipment (industry code: 29 and 30), electronics (industry code: 31 and 32), and transport machines (industry code: 34 and 35$)$ ), the majority of the firms (71.6\%) belonged to the low-tech industry such as food, textile, or wood manufacturing industry (the technology level of industry is classified based on the R\&D intensity by the OECD [66]). Vietnam was more concentrated in the low-tech industry $(91.45 \%)$, whereas Malaysia had the greatest proportion of high- and medium-tech firms $(20.18 \%$ and $25.23 \%$, respectively) among the three countries. 
Table 2. Characteristics of the sample.

\begin{tabular}{cccccc}
\hline Title 1 & Title 2 & Full Sample & Vietnam & Indonesia & Malaysia \\
\hline \multirow{2}{*}{ Industry } & High level tech (\%) & $300(12.91 \%)$ & $20(2.85 \%)$ & $168(15.74 \%)$ & $112(20.18 \%)$ \\
& Medium level tech (\%) & $360(15.49 \%)$ & $40(5.70 \%)$ & $180(16.87 \%)$ & $140(25.23 \%)$ \\
Low level tech (\%) & $1664(71.60 \%)$ & $642(91.45 \%)$ & $719(67.39 \%)$ & $303(54.59 \%)$ \\
\hline Ave. Firm age (y) & $17.36(S D=11.10)$ & $12.15(S D=10.32)$ & $20.10(S D=11.18)$ & $18.68(S D=9.52)$ \\
\hline Domestic market oriented firms (\%) & $1921(82.66 \%)$ & $453(64.53 \%)$ & $964(90.35 \%)$ & $504(90.81 \%)$ \\
\hline Listed on stock exchange (\%) & $96(4.13 \%)$ & $31(4.42 \%)$ & $9(0.84 \%)$ & $56(10.09 \%)$ \\
\hline Subsidiary of large firms $(\%)$ & $292(12.56 \%)$ & $57(8.12 \%)$ & $101(9.47 \%)$ & $134(24.14 \%)$ \\
\hline
\end{tabular}

The average firm age was $17.36(S D=11.10)$ years, but Indonesia had older firms (average firm age $=20.10$ ), while Vietnamese firms tended to be younger (average firm age $=12.15$ ). Most of the sample firms $(82.66 \%)$ sell their products mainly in the domestic market, but this pattern diminished in Vietnam (only $64.53 \%$ were domestic market oriented). Only a few firms (4.13\%) were listed. In particular, less than $1 \%$ of Indonesian firms $(0.84 \%)$ were listed, while more than $10 \%$ of Malaysian firms $(10.09 \%)$ were listed. About $13 \%$ of sample firms were subsidiaries of larger firms. While less than $10 \%$ of the firms in both Vietnam and Indonesia were a subsidiary of a larger firm, about a quarter of Malaysian firms were a part of a larger firm.

\subsection{Research Model}

To test how innovation activities affect firm performance, the following regression model (Equation (1)) was constructed. All continuous variables (top and bottom 1\%) were winsorized in order to control for the effects of extreme values.

$$
Y(\text { Annual Sales Growth })=\alpha+\beta_{\mathrm{i}}(\text { Innovation activities })+\sum \text { Control }+\varepsilon
$$

In Equation (1), the dependent variable is the firm performance proxied by the annual sales growth, which is measured using Equation (2) as follows:

$$
\text { Annual Sales Growth }=\left(\text { Sales }_{\mathrm{t}}-\text { Sales }_{\mathrm{t}-2}\right) \div\left(\left(\text { Sales }_{\mathrm{t}}+\text { Sales }_{\mathrm{t}-2}\right) \div 2\right)
$$

where Sales $t_{t}$ represents sales of the last completed fiscal year

The test variable is a firm's innovative activities proxied by product and process innovation based on the following two survey questions (refer to Table 3). Each test variable is equal to one if the answer for a survey question is yes and zero otherwise.

(1) Product_Innovation: one if the firm introduced new or significantly improved products or services during the last three years and zero otherwise.

(2) Process_Innovation: one if the firm introduced any new or significantly improved methods of manufacturing products or offering services during the last three years and zero otherwise.

Table 3. Survey questions on firm innovation.

\begin{tabular}{cl}
\hline Innovation Type & \multicolumn{1}{c}{ Survey Question } \\
\hline Product Innovation & $\begin{array}{l}\text { During the last three years, has this establishment introduced new or } \\
\text { significantly improved products or services? }\end{array}$ \\
\hline Process Innovation & $\begin{array}{l}\text { During the last three years, has this establishment introduced any new } \\
\text { or significantly improved methods of manufacturing products or } \\
\text { offering services? }\end{array}$ \\
\hline
\end{tabular}

According to Table 4434 firms (18.67\%) launched new products, while 548 firms (23.58\%) adopted new methods during the last three years. 
Table 4. Sample distribution by innovation.

\begin{tabular}{ccccccc}
\hline & \multicolumn{2}{c}{1 (answer $=$ yes) } & \multicolumn{2}{c}{0 (answer $=$ no) } & \multicolumn{2}{c}{ total } \\
\cline { 2 - 7 } & Frequency & $\%$ & Frequency & $\%$ & Frequency & $\%$ \\
\hline Product Innovation & 434 & 18.67 & 1890 & 81.33 & 2324 & 100.00 \\
Process Innovation & 548 & 23.58 & 1776 & 76.42 & 2324 & 100.00 \\
\hline
\end{tabular}

The main regression (Equation (1)) of this study also included control variables that can affect firm performance. They were firm size, firm age, percent (\%) of export from sales, percent (\%) of external financing, market type, listing status, subsidiary status, industry dummies based on the level of technology (reference group: low level), and country dummies (reference group: Malaysia). The detailed explanation for each variable is as follows.

1. Size: natural logarithm of sales.

2. Firm age: natural logarithm of firm age

3. Export: \% of export from sales

4. External finance: \% of external financing

5. Market type: one if the main market is the domestic market and zero otherwise

6. Listing status: one if a firm is publicly listed and zero otherwise.

7. Subsidiary: one if a firm is a part of a larger firm and zero otherwise.

8. High-level technology: publishing, printing, and recorded media (industry code: 22), refined petroleum product (industry code: 23 ), chemicals (industry code: 24 ), and precision instruments (industry code: 33 ).

9. Medium-level technology: plastics and rubber (industry code: 25), machinery and equipment (industry code: 29 and 30), electronics (industry code: 31 and 32), and transport machines (industry code: 34 and 35).

10. Country_Vietnam: a dummy for Vietnam.

11. Country_Indonesia: a dummy for Indonesia.

In the main test, Equation (1) was run over the total sample to test the overall effects of innovation on firm performance. We also ran Equation (1) over three subsamples based on the industry technology level (high, medium, and low level technologies) to get a more refined look into the effects of innovation on firm performance at the different technology levels.

\section{Results}

\subsection{Descriptive Statistics and Pearson Correlation}

The descriptive statistics of each variable is reported in the first two columns of Table 5. The mean and the standard deviation of the dependent variable, Annual Sales Growth, were 0.26 and 0.83 , respectively. As discussed in Table 4, 0.19\% (standard deviation $=0.39$ ) and $0.24 \%$ (standard deviation $=0.42$ ) of the sample firms were involved in product and process innovation (two test variables), respectively. The mean of each control variable was consistent with the discussion on Table 3.

Table 5 provides the Pearson correlation between each pair of the variables from Column 1 to Column 18. The test variable Product_Innovation was not significantly correlated with the dependent variable Annual Sales Growth, whereas the correlation between the test variable Process_Innovation and Annual Sales Growth was significantly negative $(-0.10)$ at the $1 \%$ level. Several control variables also had significantly negative correlation with Annual Sales Growth at the 5\% level or better: Size (0.06), Firm age (-0.15), Export (-0.04), External finance (-0.14), Listing status (-0.11), and Subsidiary (-0.06). 
Table 5. Descriptive statistics and Pearson correlation matrix $(\mathrm{N}=2324)$.

\begin{tabular}{|c|c|c|c|c|c|c|c|c|c|c|c|}
\hline No. & Variable & Mean & $S D$ & 1 & 2 & 3 & 4 & 5 & 6 & 7 & 8 \\
\hline 1. & Annual Growth Rate & 0.26 & 0.83 & 1.00 & & & & & & & \\
\hline 2. & Product_Innovation & 0.19 & 0.39 & -0.03 & 1.00 & & & & & & \\
\hline 3. & Process_Innovation & 0.24 & 0.42 & $-0.10^{* * *}$ & $0.50 * * *$ & 1.00 & & & & & \\
\hline 4. & Size & 20.55 & 5.04 & $0.06^{* * *}$ & $0.16^{* * *}$ & $0.04 *$ & 1.00 & & & & \\
\hline 5. & Firm age & 2.73 & 0.63 & $-0.15^{* * *}$ & 0.03 & 0.01 & -0.02 & 1.00 & & & \\
\hline 6. & Export & 0.18 & 0.31 & $-0.04 * *$ & $0.14 * * *$ & $0.16^{* * *}$ & $0.04 * *$ & $0.04 *$ & 1.00 & & \\
\hline 7. & External finance & 0.31 & 0.30 & $-0.14 * * *$ & $0.12 * * *$ & $0.17^{* * *}$ & -0.03 & $0.11^{* * *}$ & $0.17^{* * *}$ & 1.00 & \\
\hline 8. & Market type & 0.83 & 0.38 & $0.04 *$ & $-0.12 * * *$ & $-0.12^{* * *}$ & $-0.21^{* * *}$ & $0.07^{* * *}$ & $-0.54^{* * *}$ & $-0.06^{* *}$ & 1.00 \\
\hline 9. & Listing status & 0.04 & 0.20 & $-0.11^{* * *}$ & $0.11^{* * *}$ & $0.14^{* * *}$ & -0.03 & $0.10^{* * *}$ & $0.13^{* * *}$ & $0.15^{* * *}$ & $-0.06^{* * *}$ \\
\hline 10. & Subsidiary & 0.13 & 0.33 & $-0.06^{* * *}$ & $0.11^{* * *}$ & $0.14^{* * *}$ & -0.01 & $0.17^{* * *}$ & $0.21^{* * *}$ & $0.18^{* * *}$ & $-0.11^{* * *}$ \\
\hline 11. & High-level technology & 0.13 & 0.34 & 0.01 & -0.06 ** & -0.02 & $-0.09 * * *$ & $0.07^{* * *}$ & 0.01 & $0.06^{* * *}$ & $0.07^{* * *}$ \\
\hline 12. & Medium-level technology & 0.15 & 0.36 & $-0.03 *$ & -0.03 & 0.03 & $-0.10 * * *$ & $0.07^{* * *}$ & 0.01 & 0.02 & $0.05 * *$ \\
\hline 13. & Low-level technology & 0.72 & 0.45 & 0.02 & $0.06^{* * *}$ & 0.00 & $0.14^{* * *}$ & $-0.11^{* * *}$ & -0.01 & $-0.06^{* * *}$ & $-0.09 * * *$ \\
\hline 14. & Country_Vietnam & 0.30 & 0.46 & 0.03 & $0.24^{* * *}$ & $0.17^{* * *}$ & $0.38^{* * *}$ & $-0.38^{* * *}$ & $0.11 * * *$ & $-0.08 * * *$ & $-0.32 * * *$ \\
\hline 15. & Country_Indonesia & 0.46 & 0.50 & -0.01 & $-0.14^{* * *}$ & $-0.24^{* * *}$ & $0.30^{* * *}$ & $0.24^{* * *}$ & $-0.21^{* * *}$ & $-0.08^{* * *}$ & $0.19 * * *$ \\
\hline 16. & Country_Malaysia & 0.24 & 0.43 & -0.02 & $-0.09 * * *$ & $0.10^{* * *}$ & $-0.76^{* * *}$ & $0.13^{* * *}$ & $0.13^{* * *}$ & $0.18^{* * *}$ & $0.12^{* * *}$ \\
\hline No. & Variable & Mean & $S D$ & 9 & 10 & 11 & 12 & 13 & 14 & 15 & 16 \\
\hline 1. & Annual Growth Rate & 0.26 & 0.83 & & & & & & & & \\
\hline 2. & Product_Innovation & 0.19 & 0.39 & & & & & & & & \\
\hline 3. & Process_Innovation & 0.24 & 0.42 & & & & & & & & \\
\hline 4. & Size & 20.55 & 5.04 & & & & & & & & \\
\hline 5. & Firm age & 2.73 & 0.63 & & & & & & & & \\
\hline 6. & Export & 0.18 & 0.31 & & & & & & & & \\
\hline 7. & External finance & 0.31 & 0.30 & & & & & & & & \\
\hline 8. & Market type & 0.83 & 0.38 & & & & & & & & \\
\hline 9. & Listing status & 0.04 & 0.20 & 1.00 & & & & & & & \\
\hline 10. & Subsidiary & 0.13 & 0.33 & $0.33^{* * *}$ & 1.00 & & & & & & \\
\hline 11. & High-level technology & 0.13 & 0.34 & -0.01 & $0.09 * * *$ & 1.00 & & & & & \\
\hline 12. & Medium-level technology & 0.15 & 0.36 & 0.01 & 0.03 & $-0.16^{* * *}$ & 1.00 & & & & \\
\hline 13. & Low-level technology & 0.72 & 0.45 & 0.00 & $-0.09 * * *$ & $-0.61^{* * *}$ & $-0.68^{* * *}$ & 1.00 & & & \\
\hline 14. & Country_Vietnam & 0.30 & 0.46 & 0.01 & $-0.09 * * *$ & $-0.20 * * *$ & $-0.18^{* * *}$ & $0.29^{* * *}$ & 1.00 & & \\
\hline 15. & Country_Indonesia & 0.46 & 0.50 & $-0.15^{* * *}$ & $-0.09 * * *$ & $0.08^{* * *}$ & 0.04 * & $-0.09^{* * *}$ & $-0.61^{* * *}$ & 1.00 & \\
\hline 16. & Country_Malaysia & 0.24 & 0.43 & $0.17^{* * *}$ & $0.20 * * *$ & $0.12^{* * *}$ & $0.15^{* * *}$ & $-0.21 * * *$ & $-0.37^{* * *}$ & $-0.52 * * *$ & 1.0 \\
\hline
\end{tabular}




\subsection{Main Analysis Results}

Table 6 presents the results of the main regression over the total sample. The test variable Product_Innovation had a positive and significant impact on Annual Sales Growth, whereas Process_Innovation was likely to have significantly negative effects on Annual Sales Growth. The coefficient estimates on Product_Innovation and Process_Innovation were 0.099 and -0.190 , significant at the 5\% and $1 \%$ level, respectively. Among the control variables, Size had a positive coefficient $(\beta=0.037)$, whereas Firm age ( $\beta=-0.214)$, External finance $(\beta=-0.344)$, and Listing status $(\beta=-0.333)$ had negative coefficients, all significant at the $1 \%$ level. The maximum value of VIF (variance inflation factor) was 4.746 (Country_Vietnam), indicating that the multicollinearity problem was remote. The main results suggested that product innovation such as the introduction of new products can increase the firm performance, while the firm performance may suffer after adopting new or significantly improved methods.

Table 6. Regression results: the effect of innovation on firm performance.

\begin{tabular}{cc}
\hline Variable & Total Sample \\
\hline Intercept & $0.496^{* * *}$ \\
Test Variables & $0.099^{* *}$ \\
Product_Innovation & $-0.190^{* * *}$ \\
Process_Innovation & \\
Control Variable & $0.037^{* * *}$ \\
Size & $-0.214^{* * *}$ \\
Firm age & $-0.010^{* * *}$ \\
Export & $-0.344^{* * *}$ \\
External finance & $0.084^{* * *}$ \\
Market type & $-0.333^{* * *}$ \\
Listing status & -0.037 \\
Subsidiary & 0.030 \\
High-level tech & -0.068 \\
Medium-level tech & $-0.463^{* * * *}$ \\
Country_Vietnam & $-0.395^{* * *}$ \\
Country_Indonesia & $6.54^{*}$ \\
\hline Adj. $\mathbf{R}^{2}$ & 2324 \\
\hline $\mathbf{N}$ &
\end{tabular}

Note 1: ${ }^{* *}$, and ${ }^{* * *}$ indicate the significance based on a $p$-value less than the 5 percent level, and 1 percent level (two tailed), respectively. Note 2: To mitigate heteroscedasticity and firm clustering effects, robust standard errors are used [67].

\subsection{Additional Analysis Results at Different Industry Technology Levels}

In order to get a more refined look at the effects of innovation on firm performance at the different technology levels, we divided the sample into three subsamples based on the industry technology level (high-, mid-, and low-tech) and ran Equation (1) over the three subsamples separately. Table 7 reports the results of the additional analysis based on the industry technology level in columns High-Tech, Medium-Tech, and Low-Tech, respectively.

The additional results based on the industry technology level varied. The positive effects of product innovation on firm performance only appeared in the high-tech industry, while the negative impacts of process innovation were more prominent in the medium- and the low-tech industries. The coefficient estimate on Product_Innovation in high-tech was positive (0.35), while those on Process_Innovation at all technology levels negative (high-tech: -0.283 , medium-tech: -0.383 , low-tech: -0.117 ), all significant at the conventional level or better. The maximum value of VIF among the three regression results was 4.461 (Country_Indonesia) in the low-tech industry. In summary, product innovation seemed to contribute to firm performance mainly in the high-tech industry rather than the medium- or the low-tech industries. On the other hand, process innovation can harm the firm performance for firms in 
the medium- or the low-tech industry (In the analyses, the natural logarithm of sales was used as the proxy of firm size. Alternatively, using dummies based on the three categories of size from the WBES (large size: $100+$ employees, medium size: $20 \leq$ employees $\leq 99$, and small size: employees $\leq 19$ ), the results remained qualitatively the same. Further analysis was performed by constructing three dummies: product innovation only, process innovation only, and both innovations. Process innovation only was negatively and significantly associated with sales growth, while product process only and both innovations did not have significant relations with sales growth.).

Table 7. Regression results: the effects of innovation on firm performance at different industry technology levels.

\begin{tabular}{cccc}
\hline Variable & High-Tech & Medium-Tech & Low-Tech \\
\hline Intercept & $0.648^{* *}$ & $0.876^{* *}$ & $0.404^{* * *}$ \\
Test Variables & & & \\
Product_Innovation & $0.350^{* *}$ & 0.103 & 0.068 \\
Process_Innovation & $-0.283^{* *}$ & $-0.383^{* * *}$ & $-0.117^{* *}$ \\
Control Variable & & & \\
Size & $0.039^{* * *}$ & $0.035^{* * *}$ & $0.037^{* * *}$ \\
Firm age & $-0.408^{* * *}$ & $-0.273^{* * *}$ & $-0.163^{* * *}$ \\
Export & $0.238^{* *}$ & -0.270 & $0.013^{* *}$ \\
External finance & $-0.352^{* *}$ & $-0.425^{* *}$ & $-0.349^{* * *}$ \\
Market type & $0.386^{* *}$ & -0.075 & $0.085^{* *}$ \\
Listing status & -0.236 & -0.234 & $-0.409^{* * *}$ \\
Subsidiary & $-0.206^{* *}$ & 0.067 & 0.003 \\
Country_Vietnam & $-0.703^{* *}$ & $-0.468^{*}$ & $-0.515^{* * *}$ \\
Country_Indonesia & -0.185 & $-0.403^{* *}$ & $-0.495^{* * *}$ \\
\hline Adj. $\mathbf{R}^{2}$ & $12.50^{2 *}$ & $8.44^{* *}$ & $5.66^{\%}$ \\
\hline $\mathbf{N}$ & 300 & 360 & 1664 \\
\hline
\end{tabular}

Note $1:^{*}, * *$, and ${ }^{* * *}$ indicate the significance based on a $p$-value less than the 10 percent level, 5 percent level, and 1 percent level (two tailed), respectively. Note 2: To mitigate heteroscedasticity and firm clustering effects, robust standard errors are used [67].

\section{Discussion}

This study aimed to test the effects of innovation on manufacturing firms in Southeast Asian emerging markets. Specifically, using a cross-national sample of 2324 manufacturing firms, the current research analyzed the effects of new or improved products and methods of production on annual sales growth of the firms in Indonesia, Malaysia, and Vietnam. Like the existing literature on technology innovation [46-50], this study showed that the introduction of new or significantly improved products had positive effects on annual sales growth. New or significantly improved products contributed to customer satisfaction or protected the firm against market threats [51], which in turn led to an increase in sales. Moreover, in the current study, product innovation was defined as the introduction of new or significantly improved products. The positive relationship between product innovation and sales growth implies that a firm can benefit from the modification of existing products on the market. This suggests that open innovation commercializing external ideas can contribute to firm performance.

However, the adoption of new or significantly improved manufacturing methods was negatively related to annual sales growth. There were some possible reasons why process innovation was negatively related to sales growth. First, it may take time to see the effect of process innovation of the production on firm performance. As process innovation means a change in the way a manufacturing firm produces products, productivity can suffer while adapting to new change. Process innovation may require the introduction of new machinery or equipment, different ways of blending the raw materials, or the use of new raw materials. In addition, employees working on the production line need to become accustomed to the new production method. Adaptation often requires multiple rounds of trial and error, which can negatively impact firm productivity and performance. Similarly, the literature on open 
innovation suggests the negative relation of process innovation to firm performance may be because of constraints on the application of resources such as a lack of skilled workforce or national context [68]. A new or significantly improved equipment or technique based on up-to-date knowledge may have negative effects on firm performance when the working environment supports such changes. Moreover, according to Kraft [69], firms with higher capital intensity tend to develop process innovations. Indeed, process innovation leads to large capital expenditure, because it tends to require the purchase of new technology or machinery for reshaping internal manufacturing processes [31]. Similarly, Fagerberg [70] (p. 4) addressed that process innovation could have negative impacts on the income growth, which result in its being more prone to decrease in costs.

Another possible reason for the negative effect of process innovation on firm performance was the sample used in this study. The majority of the sample (71.6\%) belonged to the low-tech sectors. Rather than process innovation, organizational innovations may play a critical role in firm performance in low- and medium-tech industries [30]. There are different opinions about the effectiveness of process innovation in the manufacturing industry. Reichstein and Salter [31] mentioned that process innovations make small changes in the method of production, which often involves routine operational improvements. Similarly, Rosenberg and Nathan [53] regarded process innovation as a marginal area of product innovation. On the other hand, Tushman and Rosenkopf [71] (p. 313) mentioned that process innovations are the "most primitive form of innovation." For instance, lean production, a radical process innovation, can bring about huge changes for the company that adopts it.

\subsection{Implications}

The findings from this study have a number of implications. First, the current study contributes to the literature on innovation in emerging markets by providing empirical evidence about the positive effect of product innovation on sales growth. Extensive research on innovation in emerging markets has paid great attention to hurdles to investing in R\&D spending [72] or determinants of R\&D intensity [73]. Similarly, innovation is generally proxied by $R \& D$ intensity or R\&D expenditure per employee [74] rather than the introduction of a new product, which is usually more relevant to sales and therefore firm performance. The findings from the current study will be useful for understanding innovation in transitional economies by providing empirical evidence about the effectiveness of product innovation in the form of new products on a firm's performance.

This study also provides more information about the product innovation in Southeast Asian emerging markets by using a cross-national sample of manufacturing firms in Malaysia, Indonesia, and Vietnam. ASEAN is regarded as a vibrant region with a high economic growth potential of 600 million people. Despite its great potential, there has been little research that analyzes the effect of firm innovation on firm performance in the region. Like literature on other emerging markets, the literature on ASEAN has focused on the institutional characteristics of the ASEAN region. This study analyzed data at the firm level in order to test the effect of innovation on firm performance, which contributes to enriching the literature on innovation in ASEAN.

Moreover, the findings from this study will make contributions to the literature on product innovation in emerging markets by analyzing the effectiveness of the innovation and the technology levels of manufacturing industries. Despite the differences in the innovation activity between high-tech sectors and low- and medium-tech sectors, the literature on firms' innovative behaviors has paid greater attention to high-tech firms [30]. Such a trend leads to the lack of research interest in innovation in low- and medium-tech firms, a barrier to a better understanding of innovation [30,75]. This study shows that the relationship between product innovation and sales growth may be different according to the technology level, which contributes to reducing constraints to understanding product innovation.

The findings from this study have useful implications for practitioners by providing information on the effectiveness of innovation in the manufacturing sectors of Southeast Asian emerging markets. The result showed that product innovation was positively associated with annual sales growth, which implies that manufacturing sectors need to invest in production innovations in order to improve 
firm performance. In particular, the results of additional analyses displayed that for high-tech firms, product innovation can play a critical role in firm performance.

The results of this study can have further implications for governments in Southeast Asian emerging markets by providing information about how to improve the performance of manufacturing sectors. For emerging markets, the manufacturing industry makes a great contribution to solving unemployment issues [19]. The findings from this study suggest that manufacturing firms can enhance sales growth through product innovation. This implies that Southeast Asian governments need to support product innovation for the growth and development of the manufacturing sector.

\subsection{Limitations and Direction for Future Research}

Despite the strengths of this study, there are some limitations. First, this study focused on manufacturing firms in Vietnam, Indonesia, and Malaysia, which may make the results inapplicable to other emerging economies. Future research could address part of this issue by extending the methodology to other Asian emerging economies such as Thailand. It would be also interesting to explore whether the effect of innovation on firm performance differs among the ASEAN members.

Similarly, this study dealt with the effectiveness of manufacturing firms' innovation, which limits the application of the results to other industries such as service and information technologies. Therefore, future research could be conducted on other industries, particularly the service industry, because a country's economic growth needs the development of both manufacturing and service sectors.

In addition, it takes time to see the effect of firm innovation. This implies that a longitudinal study is needed in order to fully test the effectiveness of firm innovation. In this study, the outcome of firm innovation was proxied by sales growth for two years. However, for a more correct analysis, future research on the innovation effectiveness needs to be conducted on long term data.

It might be also necessary to test the effect of product innovation on firm change. Product innovation has been considered as a primary means of firm renewal $[29,43,76]$. Product innovation tends to bring big or small changes to a firm because it is likely to require the adoption of new technologies or methods in the production, human resources with new skills, or organizational changes. It takes much work before a new product is introduced to the market. However, there is little research on the relation of product innovation to firm change. Therefore, the attempt to test the effect of the product innovation on firm renewal might be helpful for a deeper understanding of product innovation effectiveness.

\section{Conclusions}

The current business environment is characterized by fast changes in customers, technologies, and competition [43]. As such, firm innovation has been considered an engine that contributes to obtaining competitive advantages over competitors [51,77] and enhances long term financial performance [78,79]. Although emerging markets have attracted much attention from scholars in the last two decades [80], there is still a need for empirical evidence on the link between innovation activities to firm performance at the firm level in these markets [81,82]. A number of studies have reported that innovation does not necessarily lead to better performance $[39,77]$. To improve the effectiveness of firm innovation, further research needs to be conducted on innovation in Southeast Asian emerging markets.

Author Contributions: Conceptualization, K.N. and Y.-H.K.; Methodology and Formal Analysis, K.N.; Writing-Original Draft Preparation, K.N. and Y.-H.K.; Writing-Review and Editing, K.N. and Y.-H.K.; Funding Acquisition, K.N.

Funding: This research was funded by the BISA Research Grant of Keimyung University in 2019.

Conflicts of Interest: The authors declare no conflict of interest.

\section{References}

1. Beaver, G. Small Business, Entrepreneurship and Enterprise Development; Pearson Education: London, UK, 2002. 
2. Atalay, M.; Anafarta, N.; Sarvan, F. The relationship between innovation and firm performance: An empirical evidence from Turkish automotive supplier industry. Proced. Soc. Behav. Sci. 2013, 75, 226-235. [CrossRef]

3. Ayyagari, M.; Demirgüç-Kunt, A.; Maksimovic, V. Firm innovation in emerging markets: The role of finance, governance, and competition. J. Financ. Quant. Anal. 2011, 46, 1545-1580. [CrossRef]

4. Krasniqi, B.A.; Desai, S. Institutional drivers of high growth firms: Country-level evidence from 26 transition economies. Small Bus. Econ. 2016, 47, 1075-1094. [CrossRef]

5. Wang, C.; Kafouros, M. What factors determine innovation performance in emerging economies? Evidence from China. Int. Bus. Rev. 2009, 18, 606-616. [CrossRef]

6. Arvanitis, S.; Stucki, T. What determines the innovation capability of firm founders? Ind. Corp. Change 2012, 21, 1049-1084. [CrossRef]

7. Na, K.; Shin, K. The Gender Effect on a Firm's Innovative Activities in the Emerging Economies. Sustainability 2019, 11, 1992. [CrossRef]

8. Canh, N.T.; Liem, N.T.; Thu, P.A.; Khuong, N.V. The Impact of Innovation on the Firm Performance and Corporate Social Responsibility of Vietnamese Manufacturing Firms. Sustainability 2019, 11, 3666. [CrossRef]

9. Shiang, L.E.; Nagaraj, S. Impediments to innovation: Evidence from Malaysian manufacturing firms. Asia Pac. Bus. Rev. 2011, 17, 209-223. [CrossRef]

10. Hartono, A.; Kusumawardhani, R. Innovation barriers and their impact on innovation: Evidence from Indonesian manufacturing firms. Glob. Bus. Rev. 2019, 20, 1196-1213. [CrossRef]

11. Grazzi, M.; Mathew, N.; Moschella, D. Efficiency, Innovation, and Imported Inputs: Determinants of Export Performance among Indian Manufacturing Firms; No. 2017/09; LEM Working Paper Series; Laboratory of Economics and Management (LEM): Pisa, Italy, 2017.

12. Lynch, R.; Jin, Z. Knowledge and innovation in emerging market multinationals: The expansion paradox. J. Bus. Res. 2016, 69, 1593-1597. [CrossRef]

13. Wei, B.; Ye, D.; Wei, J. Emerging Economies: Institutions and Entrepreneurship in the People's Republic of China. J. Enterp. Innov. Emerg. Econ. 2019, 44, 1-20. [CrossRef]

14. Groff, S. Keynote Speech: ASEAN Integration and the Private Sector. Berlin, Federal Republic of Germany. 2014. Available online: http://www.adb.org/km/node/41820 (accessed on 6 August 2015).

15. Kwak, S.; Lee, C.S.; Cheong, J.; Lee, J.; Kim, J. ASEN Integration: Changing Patterns of Trade and Direct Investment within Southeast Asia and Its Implication; Working Paper 15-17; Korea Institute for International Economic Policy: Sejong, Korea, 2015.

16. Ling, T.C.; Nasurdin, A.M. Human resource management practices and organizational innovation: An empirical study in Malaysia. J. Appl. Bus. Res. 2010, 26, 105-116. [CrossRef]

17. $\mathrm{Vu}, \mathrm{H} . \mathrm{N}$. The role of human and social capital in the development of manufacturing SMEs in Vietnam. J. Econ. Dev. 2014, 16, 5-22.

18. Malarvizhi, C.A.N.; Zeynali, Y.; Mamun, A.A.; Ahmad, G.B. Financial Development and Economic Growth in ASEAN-5 Countries. Glob. Bus. Rev. 2019, 20, 57-71. [CrossRef]

19. Pham, T.T.T.; Matsunaga, N. Product and Process Innovation of Micro, Small and Medium Manufacturing Enterprises in Vietnam. In Innovation in Developing Countries; Matsunga, N., Ed.; Springer: Singapore, 2019; pp. 23-51.

20. Rosli, M.M.; Sidek, S. The Impact of Innovation on the Performance of Small and Medium Manufacturing Enterprises: Evidence from Malaysia. J. Innov. Manag. Small Medium Enterp. 2013, 2013, 885666. [CrossRef]

21. ILO. Indonesia Jobs Outlook 2017: Harnessing Technology for Growth and Job Creation; International Labour Office: Jakarta, Indonesia, 2017.

22. Okamoto, Y.; Sjöholm, F. Technology development in Indonesia. In Competitiveness, FDI and Technological Activity in East Asia; Edvard Edgar: London, UK, 2003; pp. 375-396.

23. Chen, J.; Yin, X.; Mei, L. Holistic innovation: An emerging innovation paradigm. Int. J. Innov. Stud. 2018, 2, 1-13. [CrossRef]

24. Dosi, G. The nature of innovative process. In Technical Change and Economic Theory; Dosi, G., Freeman, C., Nelson, R., Silverberg, G., Soete, L., Eds.; Frances Pinter: London, UK, 1988; pp. 221-238.

25. Thornhill, S. Knowledge, innovation and firm performance in high-and low-technology regimes. J. Bus. Ventur. 2006, 21, 687-703. [CrossRef]

26. Freeman, C.; Soete, L. The Economics of Industrial Innovation; Pinter Press: London, UK, 1997.

27. Saviotti, P.P.; Nooteboom, B. Technology and Knowledge; Edward Elgar Publishing: Cheltenham, UK, 2000. 
28. Bowen, H.K.; Kim, C.B.; Charles, H.A.; Seteven, W.C. Development projects: The engine of renewal. Harv. Bus. Rev. 1994, 72, 110-120.

29. Dougherty, D. A practice-centered model of organizational renewal through product innovation. Strat. Manag. J. 1992, 13, 77-92. [CrossRef]

30. Hirsch-Kreinsen, H.; Jacobson, D.; Laestadius, S.; Smith, K. Low and medium technology industries in the knowledge economy: The analytical issues. In Low-Tech Innovation in the Knowledge Economy; Hirsch-Kreinsen, H., Jacobson, D., Laestadius, S., Eds.; Peter Lang: Frankfurt, Germany, 2005; pp. 11-30.

31. Reichstein, T.; Salter, A. Investigating the sources of process innovation among UK manufacturing firms. Ind. Corp. Chang. 2006, 15, 653-682. [CrossRef]

32. Kurt, S.; Kurt, Ü. Innovation and labour productivity in BRICS countries: Panel causality and co-integration. Proced. Soc. Behav. Sci. 2015, 195, 1295-1302. [CrossRef]

33. Krishnan, R.; Jha, S. Innovation Strategies in Emerging Markets: What Can We Learn from Indian Market Leaders. ASCI J. Manag. 2011, 41, 21-45.

34. Radas, S.; Božić, L. The antecedents of SME innovativeness in an emerging transition economy. Technovation 2009, 29, 438-450. [CrossRef]

35. Szirmai, A.; Naudé, W.; Goedhuys, M. Entrepreneurship, innovation, and economic development: An overview. In Entrepreneurship, Innovation, and Economic Development; Oxford University Press: London, UK, 2011; pp. 3-32.

36. Gorodnichenko, Y.; Svejnar, J.; Terrell, K. Globalization and Innovation in Emerging Markets; No. w14481; National Bureau of Economic Research: Cambridge, MA, USA, 2008.

37. Yun, J.J.; Won, D.; Park, K. Entrepreneurial cyclical dynamics of open innovation. J. Evol. Econ. 2018, 28, 1151-1174. [CrossRef]

38. Zhou, K.Z.; Yong, G.Z.; Zhao, H. State ownership and firm innovation in China: An integrated view of institutional and efficiency logics. Adm. Sci. Quart. 2017, 62, 375-404. [CrossRef]

39. Yun, J.J.; Nadhiroh, I.M.; Jung, W.Y. The relationship between open innovation, entrepreneurship, and introduction of new business models in Korean and Indonesian information technology enterprises. Kor. Soc. Sci. J. 2013, 40, 81-99. [CrossRef]

40. Yun, J.J.; Won, D.; Hwang, B.; Kang, J.; Kim, D. Analysing and simulating the effects of open innovation policies: Application of the results to Cambodia. Sci. Public Policy 2015, 42, 743-760. [CrossRef]

41. Yun, J.J.; Won, D.; Park, K.; Jeong, E.; Zhao, X. The role of a business model in market growth: The difference between the converted industry and the emerging industry. Technol. Forecast. Soc. Chang. 2019, in press.

42. Srinivas, S.; Sutz, J. Developing countries and innovation: Searching for a new analytical approach. Technol. Soc. 2008, 30, 129-140. [CrossRef]

43. Danneels, E. The dynamics of product innovation and firm competences. Strat. Manag. J. 2002, 23, $1095-1121$. [CrossRef]

44. McGrath, R.G.; MacMillan, I.; Venkataraman, S. Defining and developing competence: A strategic process paradigm. Strat. Manag. J. 1995, 16, 251-275. [CrossRef]

45. Langley, D.; Pals, N.; Ortt, R. Adoption of behaviour: Predicting success for major innovations. Eur. J. Innov. Manag. 2005, 8, 56-78. [CrossRef]

46. Alegre, J.; Lapiedra, R.; Chiva, R. A measurement scale for product innovation performance. Eur. J. Innov. Manag. 2006, 9, 333-346. [CrossRef]

47. Bayus, B.L.; Erickson, G.; Jacobson, R. The financial rewards of new product introductions in the personal computer industry. Manag. Sci. 2003, 49, 197-210. [CrossRef]

48. Hernández-Espallardo, M.; Delgado-Ballester, E. Product innovation in small manufacturers, market orientation and the industry's five competitive forces: Empirical evidence from Spain. Eur. J. Innov. Manag. 2009, 12, 470-491. [CrossRef]

49. Camison, C.; López, A.V. An examination of the relationship between manufacturing flexibility and firm performance: The mediating role of innovation. Int. J. Oper. Prod. Manag. 2010, 30, 853-878. [CrossRef]

50. Varis, M.; Littunen, H. Types of innovation, sources of information and performance in entrepreneurial SMEs. Eur. J. Innov. Manag. 2010, 13, 128-154. [CrossRef]

51. Hult, G.; Tomas, M.; Hurley, R.F.; Knight, G.A. Innovativeness: Its antecedents and impact on business performance. Ind. Mark. Manag. 2004, 33, 429-438. [CrossRef] 
52. Papinniemi, J. Creating a model of process innovation for reengineering of business and manufacturing. Int. J. Prod. Econ. 1999, 60, 95-101. [CrossRef]

53. Rosenberg, N.; Nathan, R. Inside the Black Box: Technology and Economics; Cambridge University Press: Cambridge, UK, 1982.

54. Yun, J.J.; Liu, Z. Micro-and Macro-Dynamics of Open Innovation with a Quadruple-Helix Model. Sustainability 2019, 11, 3301. [CrossRef]

55. Oke, A.; Burke, G.; Myers, A. Innovation types and performance in growing UK SMEs. Int. J. Oper. Prod. Manag. 2007, 27, 735-753. [CrossRef]

56. Wan, D.; Ong, C.H.; Lee, F. Determinants of firm innovation in Singapore. Technovation 2005, 25, $261-268$. [CrossRef]

57. Zhuang, L.; Williamson, D.; Carter, M. Innovate or liquidate-are all organisations convinced? A two-phased study into the innovation process. Manag. Decis. 1999, 37, 57-71. [CrossRef]

58. Murat, A.I.; Baki, B. Antecedents and performance impacts of product versus process innovation: Empirical evidence from SMEs located in Turkish science and technology parks. Eur. J. Innov. Manag. 2011, 14, 172-206. [CrossRef]

59. Morone, P.; Testa, G. Firms growth, size and innovation: An investigation into the Italian manufacturing sector. Econ. Innov. New Technol. 2008, 17, 311-329. [CrossRef]

60. Vivero, R.L. The impact of process innovations on firm's productivity growth: The case of Spain. Appl. Econ. 2002, 34, 1007-1016. [CrossRef]

61. Kirner, E.; Kinkel, S.; Jaeger, A. Innovation paths and the innovation performance of low-technology firms-An empirical analysis of German industry. Res. Policy 2009, 38, 447-458. [CrossRef]

62. Santamaría, L.; Nieto, M.; Barge-Gil, A. Beyond formal R\&D: Taking advantage of other sources of innovation in low-and medium-technology industries. Res. Policy 2009, 38, 507-517.

63. Robertson, P.; Patel, P. New wine in old bottles: Technological diffusion in developed economies. Res. Policy. 2007, 36, 708-721. [CrossRef]

64. Hansen, P.; Serin, G. Will low technology products disappear? The hidden innovation processes in low technology industries. Technol. Forecast. Soc. Chang. 1997, 55, 179-191. [CrossRef]

65. Cohen, W.M.; Levinthal, D.A. Absorptive capacity: A new perspective on learning and innovation. Adm. Sci. Quart. 1990, 35, 128-152. [CrossRef]

66. OECD. ISIC Rev. 3 Technology Intensity Definition. OECD Directorate for Science, Technology and Industry, 2011. Available online: http://www.oecd.org/sti/ind/48350231.pdf (accessed on 29 October 2019).

67. Petersen, M. Estimating standard errors in finance panel data sets: Comparing approaches. Rev. Financ. Stud. 2009, 22, 435-480. [CrossRef]

68. Garriga, H.; Von Krogh, G.; Spaeth, S. How constraints and knowledge impact open innovation. Strat. Manag. J. 2013, 34, 1134-1144. [CrossRef]

69. Kraft, K. Are product and process innovations independent of each other? Appl. Econ. 1990, 22, 1029-1038. [CrossRef]

70. Fagerberg, J.; Mowery, D.C.; Nelson, R.R. The Oxford Handbook of Innovations; Oxford University Press: Oxford, UK, 2004.

71. Tushman, M.; Rosenkopf, L. Organizational determinants of technological change: Toward a sociology of technological evolution. Res. Org. Behav. 1992, 14, 311-347.

72. Taymaz, E.; Üçdoğruk, Y. Overcoming the double hurdles to investing in technology. Small Bus. Econ. 2009, 33, 109-128. [CrossRef]

73. Hall, B.H.; Lotti, F.; Mairesse, J. Innovation and productivity in SMEs: Empirical evidence for Italy. Small Bus. Econ. 2009, 33, 13-33. [CrossRef]

74. Heidenreich, M. Innovation patterns and location of European low-and medium-technology industries. Res. Policy 2009, 38, 483-494. [CrossRef]

75. Hirsch-Kreinsen, H.; Jacobson, D.; Robertson, P. “Low-tech” Industries: Innovativeness and Development Perspectives-A Summary of a European Research Project. Prometheus 2006, 24, 3-21. [CrossRef]

76. March, J.G. Exploration and exploitation in organizational learning. Organ. Sci. 1991, 2, 71-87. [CrossRef]

77. Singh, S.K.; Gaur, S.S. Entrepreneurship and innovation management in emerging economies. Manag. Decis. 2018, 56, 2-5. [CrossRef] 
78. Adams, R.; Jeanrenaud, S.; Bessant, J.; Denyer, D.; Overy, P. Sustainability-oriented innovation: A systematic review. Int. J. Manag. Rev. 2016, 18, 180-205. [CrossRef]

79. Mateut, S. Subsidies, financial constraints and firm innovative activities in emerging economies. Small Bus. Econ. 2018, 50, 131-162. [CrossRef]

80. Peng, M.W.; Lebedev, S.; Vlas, C.O.; Wang, J.C.; Shay, J.S. The growth of the firm in (and out of) emerging economies. Asia Pac. J. Manag. 2018, 35, 829-857. [CrossRef]

81. Pérez, J.A.H.; Geldes, C.; Kunc, M.H.; Flores, A. New approach to the innovation process in emerging economies: The manufacturing sector case in Chile and Peru. Technovation 2019, 79, 35-55. [CrossRef]

82. Cassiman, B.; Golovko, E.; Martinez-Ros, E. Innovation, exports and productivity. Int. J. Ind. Organ. 2010, 28, 372-376. [CrossRef]

(C) 2019 by the authors. Licensee MDPI, Basel, Switzerland. This article is an open access article distributed under the terms and conditions of the Creative Commons Attribution (CC BY) license (http://creativecommons.org/licenses/by/4.0/). 